Pamiętnik Literacki 2018, 1, s. 81-94
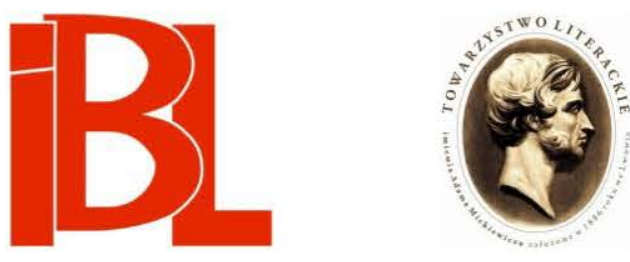

\title{
Szkic do portretu literackiego Marie
}

\section{Krysinskiej}

Ewa Małgorzata Wierzbowska 
Pamiętnik Literacki CIX, 2018, z. 1, PL ISSN 0031-0514

DOI: $10.18318 / \mathrm{pl} .2018 .1 .4$

EWA MAŁGORZATA WIERZBOWSKA Uniwersytet Gdański

SZKIC DO PORTRETU LITERACKIEGO MARIE KRYSINSKIEJ

twarz i głos zmienne i łagodne; oczy, które patrząc na wpół się przymykają i zdają się szukać tego, co miękko kryje się w cieniu; usta duże i wąskie, prawie zawsze błyszczące i uśmiechnięte; czasami jakieś rozmarzone milczenie; $z$ profilu, przy pianinie, jej włosy zdają się smutne... ${ }^{1}$

Marpha Bableuska to jeden $\mathrm{z}$ przydomków Marie Krysinskiej, wiążący się bezpośrednio z panującą wówczas atmosfera wrogości wobec le bas-bleus, ruchu intelektualnie aktywnych, tworzacych i publikujących kobiet, sawantek ${ }^{2}$. Upór, przekonanie o znaczeniu własnej twórczości, nieustanna aktywność pozwoliły jej przetrwać w mizoginistycznej atmosferze końca XIX wieku. Współczesne badania nad dorobkiem Krysinskiej dowodzą, iż miała ona ważny wkład intelektualny w filozofię i estetykę swojej epoki.

\section{Kto zacz Marie Krysinska?}

Marie Krysinska to pisarka, kompozytorka i śpiewaczka polska tworząca po francusku lub autorka francuska pochodzenia polskiego - w pracach badaczy pojawiaja się oba określenia ${ }^{3}$. Urodzona w Warszawie, w 1857 roku, w wieku 16 lat wyjechała do Paryża studiować muzykę. Żyła we Francji, z krótką przerwą na 2-letni pobyt w Stanach Zjednoczonych pod koniec lat osiemdziesiatych XIX stulecia ${ }^{4}$. 16 IX 1908 na łamach „Le Matin” zamieszczono ogłoszenie, iż umarła „Pani Marie Krysinska herbu Leliwa, literatka i muzyk" ${ }^{5}$. Jest to jedna $z$ tych piszacych kobiet, których ślad w historii kultury niemal zaginął. To dziwi, jako że Krysinska była

1 H. B a rbu s s e, Notes d'art. „L'Aurore” 1895, nr 2, z 5 XII, s. 5. Jeśli nie podano inaczej, wszystkie tłumaczenia $\mathrm{z}$ języka francuskiego pochodzą ode mnie.

2 Zob. Ch. Pla n té, Marie Krysinska: Une femme poète en France à la fin du XIX ${ }^{e}$ siècle. W zb.: Marie Krysinska. Innovations poétiques et combats littéraires. Sous la dir. de A. M. Pa liy e n ko, G. Schultz, S. Whidden. Avant-propos M. Murat. Saint-Étienne 2010, s. 29.

3 Zob. np. M. Krysinska, Poèmes choisis suivis d'Études critiques. Choix, présentation, notes S. Whid d e n. Saint-Étienne 2013.

4 Krysinska i jej mąż, Georges Bellenger, odbyli dwie podróże do Stanów Zjednoczonych w latach 1885-1887. Zob. Bellenger, Georges. Hasło w: D. K a r e l, Dictionnaire des artistes de langue française en Amérique du Nord: peintres, sculpteurs, dessinateurs, graveurs, photographes, orfèvres. Québec 1992, s. 63. - Kry sin ska, op. cit., s. 10.

5 Communiqués de la vie mondaine. „Le Matin” 1908, nr z 16 IX, s. 4. 
obecna, jako jedyna kobieta ${ }^{6}$, w kołach literackich Hirsutes, Zutistes czy Jemenfoutistes, występowała w kabaretach „Les Hydropathes” i „Le Chat noir”, publikowała w wydawanych przez nie czasopismach. Od kilku lat, głównie dzięki pracom Setha Whiddena, spuścizna Krysinskiej staje się coraz częściej przedmiotem badań literackich. W stulecie śmierci artystki, w 2008 roku, zorganizowano w Bibliotece Polskiej w Paryżu pierwszą konferencję poświęconą jej twórczości.

Krysinska wydała trzy tomiki poetyckie: Rythmes pittoresques. Mirages, symboles, femmes, contes, résurrections (1890), Joies errantes. Nouveaux rythmes pittoresques (1894) i Intermèdes. Nouveaux rythmes pittoresques (1903). Do części swoich wierszy skomponowała muzykę. Wśród tekstów prozatorskich Krysinskiej znajdują się: zbiór opowiadań L'Amour chemin. Contes en prose (1892), powieść w odcinkach Juliette Cordelin (1895), dwie powieści Folle de son corps (1896) i La Force du désir (1905) oraz nowele, eseje i kroniki publikowane w „La Fronde”, a także w innych czasopismach. Artystka wystawiała też jednoaktówki i sceny liryczne $^{7}$. W swoich utworach podejmowała m.in. kwestie kreatywności, geniuszu czy miejsca kobiet w społeczeństwie. Jej dzieło współtworzą obraz i dźwięk; charakteryzuje się ono różnorodnością źródeł i wpływów; rozmaite sztuki, literatura, nauka wchodzą w nieustanny dyskurs. W tekstach Krysinskiej mamy do czynienia ze swoistym recyklingiem ${ }^{8}$. Autorka posługuje się tym samym elementem, tym samym materiałem, umieszczając go w różnych kontekstach, rozmaicie go opracowując $^{9}$. W taki sposób Krysinska zaciera granice nie tylko między gatunkami a rodzajami, ale też między pisarstwem literackim i nieliterackim ${ }^{10}$.

Swoje zasadnicze idee dotyczące twórczości literackiej autorka Joies errantes opublikowała w feministycznym dzienniku „La Fronde”, założonym przez Marguerite Durand. Zważywszy, że Krysinska nie znosiła krytyków ani dziennikarzy, jej udział w komitecie redakcyjnym tego pisma świadczy o dużym zaangażowaniu w kwestie feministyczne ${ }^{11}$. Idee feministyczne pojawiają się zresztą w całej jej twórczości. Przez lata pokazywała ona z niesłabnacca energią, iż kobieta to - tak samo jak mężczyzna - byt obarczony słabościami, ale byt kreatywny ${ }^{12}$.

Zdaniem Christine Planté, współczesnej badaczki twórczości Krysinskiej, jej

6 Zob. J. Lévy, Les Hydropathes. Prose et vers d'Alphonse Allais, Paul Bilhaud [...]. Paris 1928, s. 12: „[...] Maria Krysinska, poetka i kompozytorka, uczestniczyła we wszystkich seansach. Sarah Bernhardt była l'hydropathe, ale honorowa jedynie".

7 Były to: Le Mariage forcé (zob. B rid a in e, Courrier des théâtres. „La Presse” 1891, nr 1163, z 13 VIII, s. 4); La Mort de Cléopatre. Scène lyrique (zob. L. X., Propos de coulisses. „Gil Blas” 1894, nr 5281, z 4 V, s. 3); Duetto (zob. C o m tes s e de Tramar, Carnet Mondain. Jw., 1899, nr 7129, z 25 V, s. 2); Kaïn. Spectacle d'ombres (anonsowany jako „nowość teatralna”. Zob. C. Mailla rd, Propos de coulisses. Jw., nr 7329, z 11 XII, s. 4. W „Le Matin” 〈nr 5768, z 10 XII, s. 5〉 ta sama prezentacja zapowiadana jest jako „misterium [składające się] z 10 obrazów”); Anniversaire. Comédie en un acte (zob. D on F a bri c e, Propos de coulisses. „Gil Blas” 1902, nr 8109, z 30 I, s. 3). Zob. A. M. Paliyenko, G. Schultz, S. Whidd en, Préface. W zb.: Marie Krysinska, s. 21.

Zob. np. opisy reklam wraz z komentarzami zawarte w studium M. Kry s in s ki ej New York d'été i w noweli Charming gentleman.

10 Zob. Paliyenko, Schultz, Whidden, op. cit., s. 21.

11 Zob. ibidem, s. 20.

12 Podobne stanowisko, choć nie było ono szczególnie lansowane, zajmowała m.in. J. Ad a m: „Kobieta jest jak mężczyzna, świadomością i inteligencją, i jak on może rozwijać się w nieskończoność, 
„wielkim błędem [...] było pisanie i publikowanie w kraju mało skłonnym do uznawania kobiet poetek i w momencie mało sprzyjającym" ${ }^{13}$. We Francji piszace kobiety, które wydały swoje dzieła, osiagnęły sukces czytelniczy i zyskały powszechną renomę ${ }^{14}$, były i nadal są lekceważone przez krytykę lub pomijane milczeniem ${ }^{15}$. Męska publiczność w znakomitej większości akceptowała tylko te teksty, które mieściły się w modelu XIX-wiecznej poezji kobiecej. To utwory prezentujące tzw. romantisme féminin ${ }^{16}$, definiowany nie historycznie, ale jakościowo.

Wedle Planté - Krysinska umyka modelowi poezji kobiecej z kilku powodów. Kobiety-poetki chętnie przedstawiane sa jako wielkie miłośnice. Ich wiersze czyta się tak, jakby bezpośrednio pokazywały pragnienia, przeżycia, jakby stanowiły poezję osobistą, autobiograficzną, skupioną na „ja” lirycznym. O ile w taki sposób można czytać Victoire Babois czy Louise Colet, o tyle Krysinska już nie. Nie ma u niej prostego przełożenia pragnienia na słowo, poetka posługuje się oryginalna, wypracowana przez siebie formą. $\mathrm{W}$ jej utworach mnożą się liczne aluzje i odniesienia kulturowe i niewiele tam miejsca na poezję osobista. Jeśli pojawia się - nader rzadko - ,ja” liryczne, ,ja” kobiece, to nie jest ono tożsame $z$,ja” autobiograficznym. Występowanie elementów żeńskich i ich wieloaspektowe potraktowanie wskazuje, że dla Krysinskiej kobieta nie była ani „definiowalna, ani możliwa do zamknięcia w przesądach"17. Figury kobiece, wydobyte $z$ historii, $z$ mitologii czy Biblii, pojawiają się we wszystkich zbiorach poetyckich Krysinskiej, jednak nie jest to motyw dominujący. Ėve, Ariane, Hélène, Marie, Magdelaine, Aphrodite, Judith, Jeanne d'Arc, Cléopâtre, La du Barry, Tanit to tylko część spośród postaci, których postrzeganie zapowiada XX-wieczne feministyczne lektury mitycznych i legendarnych figur. Krysinska rezygnuje w swej twórczości z przyjętej formy poezji kobiecej, ale nie rezygnuje $z$ pokazywania kobiet, a konkretnie kobiecości (tak jak jest ona postrzegana i przedstawiana), z prezentowania kobiecości kulturowej. Przedstawia więc kobietę taka, jaka jest w oczach mężczyzn i opisuje ich słowami, $z$ różnorodnych punktów widzenia ${ }^{18}$. Każdorazowo na zgodna z oczekiwaniami epoki/mężczyzny

dopóki jej organy nie zmęczą się lub nie wyczerpią" (cyt. za: S a n till a n e, Les Femmes féministes. „Gil Blas” 1900, nr 7603, z 11 IX, s. 1).

Plan té, op. cit., s. 28.

Warto pamiętać, że Krysinska była znana i czytana nie tylko za życia, o czym świadczy, m.in. prezentowanie jej utworów podczas spotkań poetyckich (zob. „La Presse” 1922, nr 2623, z 28 X, s. 2) czy w audycjach radiowych (jw., 1926, nr 4111 , z $19 \mathrm{~V}$, s. 1). Zdarza się, że poezja tej autorki jest inspiracją dla współczesnych artystów, jak np. S. M a ta (Une Symphonie en gris, 2014). Rzekomo - działo się tak na ich własne życzenie: „Gdy [kobiety piszące] są już niematerialne [tj. nie żyja], nie chcą, by się nimi zajmować” (B. de M a u r c e la y, Récit fantaisiste. „Le Figaro” 1925, nr 28, z 13 VII, s. 1).

Pla n té, op. cit., s. 33-34. Znakiem rozpoznania i uznania poezji kobiecej był tekst Ch. Ma u rr a s a Le Romantisme féminin. Allégorie du sentiment désordonné (opublikowany w roku 1905), który zawiera komentarze do tomików m.in. R. Vivien, A. de Noailles, L. Delarue-Mardrus, mieszczących się w ramach zarysowanych dla poezji kobiecej (nieuporządkowane uczucie 〈sentiment désordonné 〉). Nie znalazło się tam miejsce ani dla Krysinskiej, związanej ze skandalicznym, z męskiego punktu widzenia, sporem o wiersz wolny (vers libre), ani dla L. Ackermann, autorki poezji filozoficznej.

Zob. Planté, op. cit., s. 37.

Zob. ibidem, s. 41. 
wizję nakłada się inna, wyrażona głosem człowieka, bytu ludzkiego. Poetka zestawia rozmaite obrazy, często sprzeczne, mnoży odniesienia i punkty widzenia, co wymaga aktywności intelektualnej ze strony czytelnika.

\section{„Les Hydropathes” $\mathrm{i}$ „Le Chat noir”}

Związki Krysinskiej z muzyką wpisują się m.in. w jej działalność w kabaretach „Les Hydropathes” i „Le Chat noir”. Wraz z z tym pierwszym, założonym przez Émile'a Goudeau w 1878 roku, rodzi się we Francji poezja sceniczna. Projekt Goudeau jest następujący: pozwolić poetom przedstawić ich własne wiersze na scenie, wobec szerokiej publiczności ${ }^{19}$. Różni się to znacznie od deklamacji bądź recytacji w salonach czy na bankietach, w intymnym kręgu. W kabarecie twórca pojawia się przed liczną, mieszaną publicznością; nie czyta wierszy, ale mówi, śpiewa, krzyczy, improwizuje, „ucieleśnia” własny poemat przy akompaniamencie pianina, za pomoca gestów, mimiki ${ }^{20}$. Poeta nie jest już tylko poetą, lecz także reżyserem swojego tworu artystycznego. Taka poezja - jako sztuka sceniczna - łączy w sobie śpiew, taniec i ruch, na podobieństwo antycznej trójjedynej chorei czy Wagnerowskiej koncepcji sztuki totalnej ${ }^{21}$. Krysinska uczestniczyła aktywnie w działalności „Les Hydropathes" 22 i jej maniera prezentowania tekstów została ujęta przez Frédérica Auguste'a Cazalsa w rytmie piosenki ${ }^{23}$, a przez Armanda Massona w formie wiersza (Ode à Montmartre) ${ }^{24}$. Cazals satyrycznie podkreśla ekspresywność poetki, wyra-

$\mathrm{Na}$ ten temat Krysinska wypowiada się we wstępie do Intermèdes. Jej związki z R. Wagnerem w specyficzny sposób zasygnalizował Le Diable boite ux, autor rubryki Nouvelles et échos, w piśmie „Gil Blas” (1892, nr 4765, z 4 XII, s. 1): „Kocham Biel, kwiaty, brzoskwinie, Wagnera i Krysinską, ale wolę jej kochanka i basen Rochechouart”.

22 Gou deau (op. cit., s. 194) pisze o „Marylce Krysinskiej, polskiej pianistce”.

23 Cyt. za: F. R. J. Gou le s qu e, Une femme poète symboliste, Marie Krysinska, la Calliope du Chat Noir. Paris 2001, s. 88:

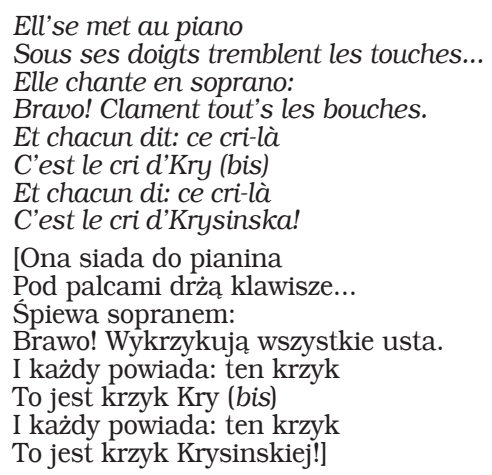

W wersji francuskiej można zaobserwować grę słów, której, niestety, nie oddaje przekład polski. Czwarta strofa tejże ody (A. M a s s o n, Ode à Montmartre. Cyt. za: P. D u fay, Au temps du Chat noir. „Ode à Montmartre”. „Le Courrier d'Epidaure. Revue médico-littéraire [...]” 1939, nr 1, s. 25) brzmi następująco:

C'était un mélange hermétique

Des produits les plus discordants; 
żającą się często poprzez krzyk; Masson zaznacza istnienie sprzeczności, nieharmonijności, które wzmacniają inność twórczości literackiej Krysinskiej. Jednak oryginalność Krysinskiej nie wystarcza, by umieścić jej nazwisko na okładce publikacji poświęconej członkom kabaretu „Les Hydropathes” (są tam wyłącznie nazwiska mężczyzn), co kłóci się z twierdzeniem pochodzącym $\mathrm{z}$ wnętrza książki, które głosi, iż „Marie Krysinska, poetka i kompozytorka, uczestniczyła we wszystkich seansach" kabaretu.

Krysinska działała aktywnie także w „Le Chat noir”, kabarecie awangardy artystycznej założonym przez Rodolphe’a Salisa w 1881 roku, w którym krąg artystów został poszerzony jeszcze o malarzy. Tym samym kabaret otworzył granice pomiędzy sztukami, co bardzo odpowiadało koncepcji sztuki autorki Rythmes pittoresques $^{25}$. W kabarecie „Le Chat noir” Krysinska pojawia się jako pianistka, interpretatorka własnych i cudzych utworów, kompozytorka muzyki do wierszy innych autorów ${ }^{26}$. Warto podkreślić, że to wkroczenie poezji na scenę wiąże się jednocześnie $z$ jej zejściem $z$ piedestału, głos bowiem został ściśle powiązany $z$ ciałem ${ }^{27}$. Zaangażowanie Krysinskiej w działalność „Les Hydropathes” i „Le Chat noir” mogło być także jedna z przyczyn usuwania tej artystki w cień; poetycka sztuka sceniczna natychmiast została uznana za sztukę niższą i jako taka, w oczach wielu ówczesnych ludzi, przynosiła ujmę, zwłaszcza kobiecie ${ }^{28}$. Należy wszakże podkreślić wagę ruchu zapoczątkowanego przez „les Hydropathes” dla XX-wiecznej sztuki francuskiej - do zaproponowanej estetyki poezji odwoływali się wpierw futuryści, a następnie letryści (Internationale lettriste) i zwolennicy bruityzmu ${ }^{29}$.

Występy Krysinskiej nie ograniczały się do scen kabaretów. W wielu miejscach, m.in. w słynnej wówczas sali koncertowo-teatralnej La Bodinière, sama lub w ze-

\author{
Symbolistes et décadents \\ Y coudoyaient l'art romantique; \\ De Krysinska les yeux charmeurs \\ Y représentaient le beau sesque \\ Sur la galère chatnoiresque \\ Nous étions quatre-vingts rimeurs \\ [Był to melanż hermetyczny \\ Najbardziej sprzecznych elementów; \\ Symboliści i dekadenci \\ Ramię w ramię ze sztuką romantyczną; \\ Krysinskiej oczy czarowne \\ Reprezentowały tu piękną pełć \\ $\mathrm{Na}$ kocioczarnej galerii \\ Było nas osiemdziesięciu rymowników].
}

Publikowanym tekstom Krysinskiej, z muzyką czy bez, towarzyszyły bardzo często rysunki, choćby Simple chanson Th.-A. St e in le n a („Gil Blas” 1895, nr 5800, z 5 X, s. 1). Poetka chętnie prezentowała swoje utwory w malarskiej scenografii, np. równolegle z ekspozycją dzieł męża (zob. B arbus s e, op. cit., s. 5).

Krysinska interpretowała m.in. poezje Ch. Baudelaire’a, Ch. Crosa, M. Rollinata. Pisała muzykę np. do tekstów Crosa, P. Verlaine'a, T. Corbière'a, A. Frémine'a, A. Massona. Zob. Le Diable b o i t e ux, Échos. „Gil Blas” 1894, nr 5462, z 1 XI, s. 1. Z kolei utwory Krysinskiej były interpretowane na scenie przez innych wykonawców, chociażby przez R. Dérigny'ego czy Madame Segond-Weber. Zob. Ga de n, op. cit., s. 69. poésie et les poétiques du XIXe siècle. Sous la dir. de Ch. Pla n té. Lyon 2002, s. 427. 
spole przedstawiała artystka muzyczno-poetyckie aranżacje swoich tekstów lub występowała w roli deklamatorki czy kompozytorki ${ }^{30}$.

\section{La bataille vers-libriste ${ }^{31}$}

La bataille vers-libriste rozpoczęła się w połowie lat osiemdziesiątych XIX wieku. W roku 1883 na łamach „La Vie moderne” Gustave Kahn opublikował swój pierwszy wiersz wolny. W tym samym roku i w tym samym czasopiśmie swoja poezję prezentowała także Krysinska ${ }^{32}$. Kahn czuł się twórcą nowej formy poetyckiej mimo faktu, iż w latach 1881-1882 Krysinska ogłaszała drukiem poematy zgodne z estetyką, która uznał za własną. Oskarżona przez Kahna o plagiat formalny poetka została wciągnięta w spór o wolny wiersz, z którego $n b$. wyszła zwycięsko, udowadniając, że jej utwory pojawiły się wcześniej niż te Kahna ${ }^{33}$ :

Jeśli zauważymy analogie między naszymi wierszami wolnymi a tymi zawartymi w tomach i broszurach, które ukazały się w ostatnich latach, przypominamy uprzedniość dat publikacji [naszych utworów] (1881-1882), aby uszanowano własność naszej inicjatywy, dobrej lub złej ${ }^{34}$.

- powiada Krysinska we wstępie do tomu Joies errantes. Pisarka nie pozwoliła na pomniejszenie swojej roli we wprowadzaniu wolnego wiersza do poezji francuskiej, ale jej rewindykację niedobrze przyjęto w środowisku ${ }^{35}$. XIX-wieczna Francja nie uznawała oryginalności twórczości kobiecej, traktując ją a priori jako imitacyjną w stosunku do twórczości mężczyzn. Krysinska podjęła próbę walki o swój wkład i współcześni oraz późniejsi krytycy ukarali ją za to wykluczeniem.

Z punktu widzenia historii literatury [...] rewindykacja inwencji formy i chęć jej samodzielnej teoretyzacji stanowi najsilniejszą ekstrawagancje [poetki] i z pewnością jest jednym z poważniejszych wyjaśnień wyjątkowej wrogości, z jaką się spotykała ${ }^{36}$.

Krysinska początkowo próbuje godzić obronę swego stanowiska ze skromnością, której doxa domaga się od kobiet, ale przy zastosowanym wobec niej ostracyzmie

30 Np. skomponowała muzykę do poezji J. Lorraina. Zob. Concerts et divertissements. „Le Matin” 1896, nr 4686, z 27 XII, s. 4.

31 Tj. spór o wiersz wolny. Szerzej na temat batalii Krysinskiej o wiersz wolny zob. E. M. Wier zb o w s k a: Autour du vers libre. Le cas de Marie Krysinska (Ire partie: 1885-1900). „Cahiers ERTA” 2016, nr 10; Autour du vers libre. Le cas de Marie Krysinska (II ${ }^{e}$ partie. Après 1900). Jw., 2017, nr 11.

Zob. S. Wh id d e n, Leaving Parnassus. Amsterdam - New York 2007, s. 116. Autor ten twierdzi, że publikacja Le Hibou M. Krysin skiej w 1883 roku w „La Vie moderne” wywołała pierwsze dyskusje na temat wiersza wolnego między nią a Kahnem.

Debiutancki zbiór poezji G. Kahna pochodzi z 1887 roku (Palais nomades), M. Krysinska zaś prezentowała na scenie (od końca lat siedemdziesiątych XIX wieku) oraz publikowała swoje utwory znacznie wcześniej: Chanson d'automne. „Le Chat noir” 1882, nr 40, z 14 X, s. 2; Symphonie en gris. Jw., nr 43, z 4 XI, s. 4; Ballade. Jw., nr 46, z 25 XI, s. 2; Berceuse macabre. Jw., nr 47, z 2 XII, s. 4.

34 M. Krysinska, Avant-propos. W: Joies errantes. Nouveaux rythmes pittoresques. Paris 1894, s. V.

35 Zob. E. Raynaud, La Mêlée symboliste. Portraits et souvenirs. T. 1: 1870-1890. Paris 1920, s. 140.

36 Planté, op. cit., s. 38. 
nie daje to oczekiwanych efektów ${ }^{37}$. We wstępie do ostatniego zbiorku, Intermèdes, poetka wyzbywa się tej postawy i wyraźnie oskarża mężczyzn o przywłaszczenie sobie całej domeny literackiej (s. V-IX) ${ }^{38}$. Należy też podkreślić, że niechęć do Krysinskiej była potęgowana faktem, iż nie była ona Francuzką ${ }^{39}$. Obrońcy czystości języka ${ }^{40}$ mieli w ręku dodatkowy atut, by nie uznawać za wartościowa jej poezji, choć w rzeczywistości bardziej chodziło tu o wiersz wolny i odmienną, waleczną, domagającą się swego postawę Krysinskiej ${ }^{41}$, bywającej w miejscach zarezerwowanych dla mężczyzn. W trakcie gorących dysput na temat początków wiersza wolnego jedni krytycy czynią z Krysinskiej nowatorkę, uznając, iż jej poematy zapowiadaja symboliczny vers-librisme, drudzy, w mniejszości, zarzucaja jej brak inwencji twórczej; jeszcze inni po prostu wyrażaja swój podziw dla piękna poezji Krysinskiej ${ }^{42}$.

\section{„Zbyt uczona przedmowa [... $]^{\text {"43 }}$}

We wstępie do ostatniego zbioru, Intermèdes, z 1903 roku, zatytułowanym Introduction sur les évolutions rationnelles ${ }^{44}$, Krysinska zapytuje, dlaczego jej nazwisko nie figuruje $\mathrm{w}$ manifestach dotyczacych wiersza wolnego, dlaczego jej poematy z 1881 roku zostały przypisane geniuszowi zbiorowemu. I sama sobie na to pytanie odpowiada: „Inicjatywa wychodząca od kobiety - tak prawdopodobnie stwierdziła

Zob. ibidem.

M. Krys in ska, Introduction sur les évolutions rationnelles. W: Intermèdes, nouveaux rythmes pittoresques. Pentéliques, guitares lointaines, chansons et légendes. Paris 1903. W dalszej części artykułu wszystkie cytaty z Introduction pochodzą z niepublikowanego tłumaczenia A. D e ls i pé e i E. M. Wi e r zbow s ki ej. Lokalizuję je podając w nawiasie numery stronic.

Krysinska była bardzo wyczulona na melodię frazy - we wszystkich tekstach, niezależnie od gatunku. Stąd liczne powtórzenia, aliteracje, asonanse, gry językowe. Aby zachować w jak największej mierze specyfikę tego stylu (dodajmy, zdecydowanie XIX-wiecznego), tłumaczki sięgały do form przestarzałych, próbując oddać nie tylko znaczenie tekstu, ale i jego brzmienie. Pozostawiły również niekonsekwencje poetki w pisowni małą i wielką literą.

Zob. Planté, op. cit., s. 39.

Do zjadliwych krytyków Krysinskiej jako nie-Francuzki zaliczyć należy J. E r n e s t a - C h a r le s' a (La Vie littéraire. Livres des femmes. „La Revue politique et littéraire. Revue bleue” 1905, nr 22, z 3 VI, s. 699), który o jej stylu pisze: „czasami francuski”.

1 Tak więc np. na łamach „Le Figaro” (1895, nr 31, z 3 VIII), M. Kry sin s k a podejmuje dyskusję z A. de Croze - publikujac przeprowadzony z nia wywiad, krytyk ten m.in. przypisywał jej opinie, których nie wypowiadała, lub przekręcał sformułowania opublikowane w przedmowie do Joies errantes.

Zob. np. A. B a d in, Bulletin bibliographique. „La Nouvelle revue” 1894, s. 221. Rythmes pittoresques i Joies errantes były sławione przez takich admiratorów, jak A. Scholl, F. Fénéon, G. Montorgueil, P. Gille, H. Bauer, A. France etc. Zob. A. de Croze, Marie Krysinska. „Le Figaro” 1895, nr 28, Z 13 VII, s. 111.

Sformułowanie użyte przez Rachild e (Joies errantes par Marie Krysinska 〈Lemerre). „Mercure de France" 1894, août, s. 386) po lekturze Introduction sur les évolutions rationnelles, wstępu Krysinskiej do Intermèdes.

Wcześniej, bo już w 1890 roku, F. F é né o n (Marie Krysinska. Rythmes pittoresques. „Art et critique" 1890, nr z 1 XI. Cyt. za: L. B rog n i ez, Marie Krysinska et le vers libre. L'outrage fait aux Muses. W zb.: Masculin/Féminin dans la poésie et les poétiques du XIXe siècle, s. 435) zwraca uwagę na brak nazwiska poetki w „symbolistycznych ewangeliach”, uznając, iż jest to przesada w zachowaniu dyskrecji implikowanej przez kobiece nazwisko. 
grupa [chodzi tu o osoby zgromadzone wokół Kahna, Moréasa i Mendèsa - E. M. W.] - może być uważana za przychodzącą znikąd, i poddana prawu domeny publicznej" (s. XXI).

Poetka, podejmując dyskusję z Kahnem na temat swojego pierwszeństwa w inwencji wiersza wolnego, kładzie nacisk na brak uznania Geniuszu w momencie, kiedy okazuje się, że twórca jest kobieta. Wpisując się w stosunkowo świeży nurt darwinizmu we Francji ${ }^{45}$, Krysinska akceptuje termin „ewolucja” jako „podażanie ku lepszemu”, co jest dlań prawdziwe „na płaszczyźnie fizjologicznej” (s. V). Poetka uważa jednak, że byłoby „wielkim błędem zastosować te prawa do dzieł artystów, do produkcji Myśli i Marzeń ludzkich, jedynie bowiem Sztuka jest uprawniona, by bezpośrednio osiagnąć Absolut” (s. V); tym samym artystka odrzuca teorie Darwina odnośnie do geniuszu męskiego, powstałego w wyniku ewolucyjnej selekcji.

Krysinska formułuje swoją własną definicję geniuszu. Geniusz objawia się nieoczekiwanie w jednostkowym dziele, a płeć nie ma tu żadnego znaczenia: „Za każdym razem, kiedy objawia się indywidualność, wyposażona w siłę kreacyjną, tworzy się styl” (s. VI). I to on będzie doznawał transformacji, ewoluował z wiekami. Wszelkie zmiany, „nieprzewidziane kombinacje” następuja „bez naruszania praw fundamentalnych i niezawisłych, niewzruszonych praw Równowagi, Harmonii i Logiki” (s. VI-VII). Gdyby przyjąc ewolucyjny charakter geniuszu, „Dante byłby chronologicznie osiem wieków niżej niż pan d'Annunzio", a malarstwo renesansu - „skromnym kompostem” dla nowoczesnego impresjonizmu (s. VI). Objawianie geniuszu „nie następuje sukcesywnie, zatem czas ledwie miniony nie jest najbardziej zaawansowany w doskonałości” (s. VI). Style, „doskonałe w swojej zróżnicowanej charakterystyce - renesans, XVII i XVIII wiek [...]", nie powinny być uznane za postęp, ale „za równowagę w pięknie” (s. VII). Wedle Krysińskiej geniusz w istocie swej stanowi „najbardziej namacalny obraz Absolutu”, który nie podlega żadnemu postępowi, „Jest spontaniczny i zmienny w nieskończoność” (s. VI). Przebłyski geniuszu, niewyjaśnione i nieprzewidywalne, mogą być rozpoznane jedynie w wytworach ludzkiej myśli. Geniusz nie ma psychofizjologicznej proweniencji, nie daje się lokalizować w ciele, ale w dziele. To siła twórcza nie obwarowana żadnymi uwarunkowaniami (s. V-IX).

„Ewolucja filologiczna również nie dokonuje się w przemyślanym kierunku postępu, jest ona tylko ciągiem różnie motywowanych wariantów" (s. VII), twierdzi Krysinska, pokazując równoległy rozwój języka i literatury. Tak więc np. przedstawiając początki języka romańskiego (XII wiek), zwraca uwagę na wpływy arabskie (precyzja, symetryczna woluta, rym - nieznane w łacinie czy hebrajskim), których odbiciem będzie w XIX wieku „parnasistowska zasada, avant la lettre, ze swymi rygorami [...]”. W XII-wiecznym poemacie Bertrama de Borna „wszystkie chwyty parnasu są już praktykowane, $z$ alternacją rymów włącznie”. Rozwój języka objawiał się $\mathrm{w}$ „postępującym wysiłku, by uwolnić się z wszelkiego obcego wpływu [...]” (s. VIII). Rozwój poezji - w alternacji rygoru i swobody w zakresie prozodii. Krysin-

45 Darwinizm przyjmował się we Francji dość wolno, co wynikało $z$ faktu, iż ewolucjonistyczna teoria J.-B. de La mar ck a pomieszczona w jego Filozofii zoologii z 1809 roku wyprzedzała publikacje Darwina o 50 lat. Teoria Darwina nie była tu postrzegana jako coś rewolucyjnego, a samego Darwina uznawano za osobę przypisująca sobie osiągnięcia innego badacza. 
ska zauważa, iż „Pierwsze prawdziwe wdzięki umysłu, pierwsze subtelności uczuć są związane z większą wolnością prozodyczną" (s. IX). Odnosi się przy tym do stanowiska Madmoiselle de Gournay, która przeciwstawia się purytańskiej poprawności:

Czy chcemy lepiej bronić tworzenia wierszy narzucając ich rymowanie? Jak bowiem byłoby możliwe, że poezja ulatywałaby ku niebu, jej celowi, z takimi strzępami skrzydeł i, co więcej, $z$ okaleczeniem i cierpieniem? [s. XI]

Wolność prozodyczna wiąże się $\mathrm{z}$ wolnością w zestawianiu samogłosek. Tu Krysinska przywołuje autorytet Charles'a-Augustina de Sainte-Beuve'a, każącego zapomnieć „zbyt wyłączną zasadę Malherbe'a”, „reformatora najeżonego arbitralnymi wymogami względem prozodii” i pozwolić sobie na „nagromadzenie samogłosek [...], które podoba się i które wypadałoby zachować" (s. XI). Poetka zauważa, że autorzy, uwolniwszy się od rygorystycznej reguły, są siłą napędową ewolucji prądów myśli. I przypomina słowa Eugène’a Melchiora de Vogüégo ${ }^{46}$ : „Wielki pisarz musi zawsze odnawiać instrument, którym się posługuje" (s. XII). Uznanie, że jakaś forma poetycka osiagnęła „nieprzekraczalną perfekcję” (s. XIII), jest dziecinada, albowiem formy poetyckie nieustannie ewoluują. Jednym $z$ elementów wpływających na kształt wiersza jest chociażby wymowa, inna w różnych regionach i zmieniająca się $\mathrm{z}$ wieku na wiek. „Naturalne jest, że język mówiony ma swoje wierne odbicie w poezji pisanej współcześnie”, powiada Krysinska i cytuje Abla François Villemaina: „Niech każdy wiek pisze językiem, którym mówi” (s. XIV). Ale decydentem zawsze jest twórca:

Naszym skromnym zdaniem, mistrzowie dawni i mistrzowie współcześni, piszący wedle dawnej tradycji, powinni być recytowani w sposób ozdobny, przy zachowaniu fonetyki, która rządzi symetrią ich dzieł - i broń Boże, byśmy nie dawali współczesnym poetom prawa pozostania wiernymi tej formule i tworzenia jeszcze według niej mistrzowskich dzieł, jeśli mają oni [ku temu] talent. [s. XV]

Aktualne reguły wymowy niszczą niegdysiejszą miarę wiersza i na odwrót: niegdysiejsza wymowa, zastosowana do wiersza współczesnego, zdeformowałaby jego miarę. Współczesna zaś formuła wiersza, „zmodyfikowana wedle fonetyki aktualnej” (s. XV), jest równie uprawniona do istnienia, co dawne.

Namiętnie podziwiamy dzieła mistrzów XVII wieku, wielkich romantyków i niektórych wspaniałych parnasistów - każdy [był] mistrzem innowacji w swoim gatunku; ale czy muszą oni być naśladowani przez kolejne pokolenia i czy ewolucja zamyka się na panu Sullym-Prudhommie? [s. XXVII]

- zapytuje autorka Rythmes pittoresques.

Poeta, jak każdy inny twórca sztuki, ma prawo ustanowić się arbitrem własnego dzieła w tym, co dotyczy używanych środków. Ale prawdziwy artysta właśnie [wówczas], kiedy postępuje wedle [...] fantazji, jest bezwzględnie ukierunkowany w swoich utworach przez tradycję piękna, utwierdzoną przykładem Mistrzów Przeszłości. [s. XXXVIII]

Krysinska podejmuje dyskusję z teorią Sully'ego-Prudhomme’a, zawartą w jego Testament poétique. Sully-Prudhomme przedstawia w nim „teorię wiersza regularnego zbudowaną na dogmacie „Najmniejszego wysiłku” - jest to wyjaśnienie początków wersyfikacji. „Najm ni ej szy wy sił ek mnemotechniczny był, oczywi- 
ście, celem pierwszych śpiewaków i opowiadaczy, którzy, przed [wynalezieniem] druku, powierzali swoje poematy jedynie pamięci swoich współczesnych" - potwierdza Krysinska i od razu zaznacza, że „ta konieczność organizowania największych ułatwień dla pamięci nie może być zasadniczym zajęciem współczesnej poezji” (s. XV-XVI). Jak „największe uproszczenie arytmetyczne zastosowane do miary wiersza”, do którego zachęca Sully-Prudhomme, „N a j m n i ej s zy w y s ił e k [włożony w skupienie] uwagi jest przezeń uznawany za gwaranta największej przyjemności i najsilniej zaznaczonego charakteru muzykalnego" (s. XVI). Dla Krysinskiej to kwestia dyskusyjna, wiąże się bowiem $z$ „trudną do tolerowania monotonia” (s. XVI), narzuceniem cezury i jednego rytmu dla różnych form ekspresji poetyckiej. Nie godząc się z teorią Sully'ego-Prudhomme'a, Krysinska znajduje z nim punkt wspólny: otóż „Pan Sully-Prudhomme - zbyt wytrawny estetyk, by słabo znać cnoty Ni e s p od zi a n ki w sztuce - poleca ją i zachwala [...]” (s. XVI). Owa „N i e s p od zi a n ka” zbieżna jest z pojęciem „D y s o n a n s u” (użytym wcześniej przez Krysinską ${ }^{47}$ ) jako „Zmiany rytmiki i jej załamania, które maja na celu [uzyskanie] cennego efektu czegoś nieoczekiwanego i zerwanie monotonii”.

Skonfrontowana z [teoria] pana Sully'ego-Prudhomme'a teoria ta [tj. teoria Dys onansu] jest utworzona w takim samym celu: by osiągnąc jak najwięcej przyjemności dla ucha i możliwie jak najwięcej muzyki dzięki eurytmii, opierającej się na podwójnym przeciwstawieniu układów symetrycznych i układów asymetrycznych - widzimy to również we wszystkich innych sztukach, korzystając, jak one, z efektów opozycji i kontrastów. Na przykładzie muzyki współczesnej - przyznajemy obszerniejszą część Dy s o n a n s om i, jak ona, uzyskujemy efekty crescendo poprzez prog r e sję rytmiczną i efekt przeciwny poprzez re g r e sję. [s. XVII]

Nową deklarację programu poetyckiego Krysinska formułuje następująco: „bardziej otwarcie wyznawane zaufanie do cnót różnorodności i, w konsekwencji, do malowniczości; pauzy następujące dowolnie i wedle potrzeby precyzji stylistycznej” (s. XVII). Ustala też maksymalną długość wiersza na 15 sylab, akceptuje „Zwykłą ciszę "e" niemego” oraz nie bierze pod uwagę „pisowni końcówek słów łączonych ze względów akustycznych”, co otwiera „bogate pole najróżniejszym modalnościom” (s. XVII-XVIII). Zaznacza nadto, iż „W razie konfliktu między najodpowiedniejszą ekspresją a najbardziej ortodoksyjnym rymem, asonans jest lepiej widziany niż rym" (s. XVIII). Przypadkowość i dysharmonia są dla Krysinskiej błędami, zatem „prawa Równowagi” muszą być zachowywane z takim samym szacunkiem przez poetów „regularnych”, jak i twórców wiersza wolnego. Autorka Introduction sur les évolutions rationnelles jasno określa wymogi wobec „poematu pisanego wierszem wolnym":

1. Aby wyrażał językiem jasnym, bez nadmiaru i rozwlekłości, jakąś myśl, ewokację, opis lub zwierzenia, które są tego warte.

2. Aby dzieło sztuki zrównoważonej nie było przedmiotem zwątpienia dla żadnego czytelnika bądź kompetentnego słuchacza.

3. Aby jego propozycja rytmiczna i muzyczna była, tak jak w wierszach tradycyjnych, oczywista, mimo poszerzeń ram prozodycznych i użycia liczb mniej powszechnych (11, 13, 14 lub 15 sylab). [s. XVIII]

47 Testament poétique został opublikowany w 1901 roku, M. Kry s in s k a o „Dy s o n a n s i e” pisała w artykule w „Revue universelle” z 1900 roku. 
Trzon swojej estetyki Krysinska określiła już w przedmowie do wcześniej wydanych Joies errantes, której fragment przywołuje w Introduction sur les évolutions rationnelles:

U początków sztuka asonansu czy rymu, sztuka pauzy symetrycznej była genialnym pomysłem jednego twórcy - pierwszego, który spostrzegł ich wartość - a nie racją bytu poezji. Tylko rytmiczność jest znacząca; ale kto mówi „rytm”, jest daleki od powiedzenia „symetria”. [s. XX]

Poetka-kompozytorka dostrzegła możliwość zastosowania w utworze poetyckim środków występujących w muzyce.

jako muzyk, za pomocą środków literackich usiłowałam przełożyć impresję muzyczną, z jej kaprysem rytmicznym, czasami nieporządkiem; używając środków prozodycznych jako ornamentów i ozdób dowolnie połączonych, bez obligatoryjnej symetrii. [s. XXII]

\section{I uściśla:}

moja nowa próba ogranicza się do bardzo skromnego wkładu: wiersze mierzone jedynie dla ucha, wedle współczesnej potocznej wymowy, i asonanse tylko dla ucha, z umiejętnością rymowania liczby mnogiej z liczbą pojedynczą i wszystkich końcowych „e” niemych, niezależnie od ich pisowni („Revue universelle”, 2 lutego 1901). [s. XX]

Krysinska stanowczo odmawia konieczności poddania się tyranii rymu, zwłaszcza rymu dla oka:

Nasza wolność polega na: rymowaniu lub tworzeniu asonansów tylko dla ucha (bez kłopotania się o liczbę pojedynczą i mnogą) wersów, które poruszają się [w rytm] pauz alternujących, rezerwując efekt rymu bogatego lub aleksandrynu dla zwieńczenia strofy, która zamyka się w ten sposób złotą ozdoba jak miękka draperia - tak, aby w zestawieniu z monotonią chwytu efekt był niespodziewany. [s. XXVIII]

Na początku lat osiemdziesiątych XIX wieku „potrzeba reakcji wydawała się naprawdę odczuwalna” (s. XXI), twierdzi Krysinska. I wyjaśnia:

Wokół parnasistowskich mistrzów, jakież zamieszanie!

Jakiż niedosyt nowych, jasno wyrażonych myśli! Jakie zadziwiające użycie języka z zachowaniem metrum tam, gdzie powinno go nie być! Wierszowany naturalizm, sztuka z pięcioma aktami [napisana] nie dającymi się słuchać aleksandrynami, filozofowanie, mówić-by-nic-nie-powiedzieć, astronomia, geografia, nadmierne informacje o stanie uczuć sygnatariusza - uznanego a priori za najbardziej interesujący przedmiot na świecie - liczne biuletyny na temat relacji ze swoją ukochana.

Trzy czy cztery mierne idee rozpuszczone w trzech lub czterech milionach stóp ułożonych w porządku, banały, [...], kompilacja słownika rymów; i jako patologia poetycka: męcząca zadyszka, inwersje nie do zaakceptowania, monotonne mruczenie, huśtawka i metronom, dusząca czkawka nieszczęśnika, który ma szyję ściśniętą sznurem i wszystkie stopy powiązane arytmetycznie.

Widzimy zatem powódź wierszokletów zaambarasowanych nadmiarem, którego wymaga obligatoryjny metraż, tonących w galimatiasie - z powodu trudności źle przezwyciężanych - mówiących jak analfabeci, doprowadzony do granic ostateczności przez tyranię rymów, władzę cezury i nieustępliwość spółgłoski zamykającej. [s. XXI-XXII]

Takie oto refleksje popchnęły Krysinską do poszukiwania nowej formy ekspresji poetyckiej: „Formuła parnasistowska bowiem nie jest wcale Formą jedyną i wyłączną” (s. XXVII). Poetka powołuje się na Victora Hugo, który explicite wskazuje na konieczność przekraczania reguł i „kpi sobie widocznie z teoretyków i geometrów literackich, ufa jedynie geniuszowi, by uprawomocnić każdą nowość” (s. XXXV).

Nowa formuła poetycka pojawiła się w wielu manifestach i wartościowych dzie- 
łach. Znaleźli się jednak i tacy, „którzy w tej próbie reformy widzieli tylko autoryzację dla siebie, by pisać byle co i byle jak" (s. XXVI). Wobec nich Krysinska była szczególnie krytyczna, dołączyła swój głos do innych krytyków, z zastrzeżeniem, że krytykować należy nie inicjatywę reformatorską, ale miernoty, które, nieudolnie, próbują posługiwać się formułą wiersza wolnego.

nie mają oni żadnego usprawiedliwienia, żadnego specjalnego wytłumaczenia, by można było zaakceptować zarzucaną im niejasność, do którego mieliby prawo [poeci] związani rygorystycznymi prozodiami, następcy mistrzów parnasistowskich, stłamszeni przez konwencjonalne wymogi. [s. XXVI]

„Niejasność języka jest - kładę na to nacisk - szczególnie nie do zaakceptowania u poetów [uprawiających] wiersz wolny" (s. XXVIII).

Nasza troska była [...] troską stylisty, który chce absolutu słowa w poezji, podobnie jak w prozie, który nie ufa nieokreśloności, zna niebezpieczeństwo nadmiaru, [niebezpieczeństwo] błędów, ku jakim niewzruszone metryki pociagają swoich obrońców. [s. XXVII]

Krysinska przypomina, że jeśli w stosunku do własnej poezji usłyszała „wiele pochwał pomieszanych $z$ rezerwą względem nowej formuły”, to „zarzut pisania niejasnym językiem nie został [jej] nigdy postawiony" (s. XXVIII). Poetka przywołuje krytyków swoich utworów: Auréliena Scholla, Philippe’a Gille’a, Féliciena Champsaura, Josepha-Henriego Rosny'ego, Cadillaca, Charles'a Maurrasa, Anatole'a France'a. Ten ostatni, „artysta wolny, oryginalny i ciekawy” (s. XXXII), okazał się krytykiem mało rzetelnym, albowiem za prawdziwe przyjął oświadczenie Jeana Moréasa i Gustave'a Kahna, jakoby byli oni nowatorami, twórcami nowej estetyki. France nie zweryfikował tej informacji, choć mógł to uczynić dzięki materiałom czasopiśmienniczym, dostępnym w Bibliothèque nationale. Podobnie zresztą uczynił Charles Le Goffic, który przyznał palmę pierwszeństwa w stworzeniu formuły wiersza wolnego - „monstrum horrendum informel ingens” (s. XXXV) - Krysinskiej i Kahnowi ${ }^{48}$. Poetka wykazuje się odwagą, nie waha się wyrażać głośno swojej opinii i wskazuje, bez deprecjonowania krytyków, gdzie popełnili błąd.

Krysinska podejmuje też dyskusję z Kahnem, który, w książce Symbolistes et décadents, sam rozwiązuje kwestię pierwszeństwa, ogłaszając się twórcą wiersza wolnego: „J a two r zyłe m s zkołę"49. Poetka konsekwentnie przypomina chronologię publikacji i z ironią puentuje wyznania Kahna: „Szczęśliwy klimat afrykański i szczęśliwy wiek, w którym można tworzyć s zkołę, zanim wydrukowało się choćby jedną linijkę odkrywającą wła s ną estetykę!” (s. XXXIV).

Należałoby podkreślić, że Krysinska nie jest zwolenniczką szkół:

niezręcznością i błędem jest sądzić twórców sztuki klasyfikując ich grupami, klanami lub szkołami. Dzieło artystyczne jest coś warte tylko z racji osobistego znamienia, które autor mógł w nim pozostawić, jest ono unikatową esencją. Trzeba zatem sądzić artystów osobno. Sam fakt przynależności [wiąże się z] degradacją i stanowi powód do braku zainteresowania wśród rozumnych krytyków.

W sztuce nie chodzi o bycie Jezusem otoczonym swoimi uczniami, ale po prostu [o bycie] artysta doświadczającym, w szczerości własnej świadomości, pragnienia wyrażenia się, dotknięcia jakiejś nowej

Ch. Le Goffic (Intermèdes. 〈Nouveaux Rythmes pittoresques〉, par Marie Krysinska. „Revue universelle” 1904, nr 118, s. 509), po weryfikacji rzeczonych materiałów naprawia swój błąd i przyznaje palmę pierwszeństwa Krysinskiej. 
struny i wybierającym w tym celu formułę, która mu najbardziej odpowiada; bez najmniejszej pretensji do bycia naśladowanym, wręcz przeciwnie, $z$ nadzieją, że się nie będzie [naśladowanym]. [s. XXXVI]

\section{I poetka zdecydowanie dodaje:}

Nie mając nigdy ambicji, by zajmować stanowisko założyciela szkoły, z energią odsuwam tytuł ucznia i cytuję - jako świadków mojej niezależności - daty publikacji, które czynią mnie [moje dzieło] u przednia [w stosunku] do formacji nowatorskiej grupy, ogłaszającej, przez systematyczne pomijanie mojego nazwiska, moje nieistnienie i nieprzybycie; „mit” [założycielski] - napisał dosłownie, nie wiem już gdzie, pan Viellé Griffin. [s. XXXVI-XXXVII]

\section{Na zakończenie swojej „zbyt uczonej przemowy” Krysinska przypomina:}

Poezja jest przede wszystkim literaturą i może być wyrażona w najswobodniej oddychającej prozie; Bossuet, Chateaubriand, Flaubert sa poetami.

Jeżeli wersyfikacja nie byłaby pojęciem scholastycznym, którego definicja zmienia się wraz z rasami i czasami, Salomon, Dawid, Homer, poeci łacińscy, nie stosujący rymu, angielscy: Shelley i Tennisson, nasz Lafontaine (nie zmuszał się on do żadnej regularnej pauzy), nie byliby wcale poetami.

Forma i Ry tm nie są wcale synonimami sy metri i; ,miara” jest słowem złożonym i obszernym, które w muzyce unosi się ponad podziałami zmieniającymi się w nieskończoność. Jakże cudowny jest wielki Schumann w swojej rytmicznej i harmonijnej nieprzewidywalności. [s. XXXVIII]

To nawiązanie do muzyki okazuje się szczególnie ważne, ponieważ Krysinska posługuje się w poezji znakami topograficznymi analogicznie do pauz muzycznych.

Wiersz wolny z końca XIX wieku to twór żywy, a nie forma stała. Każdy verslibriste wypracowywał własną technikę pisania. Niewątpliwie Krysinska posługiwała się swoją osobistą formą wiersza wolnego. Początkowo w jej poezji nie było rymów, potem pojawiają się rymy, te dla ucha, asonanse i kontrasonanse, czasem rymy homonimiczne. W dwóch ostatnich zbiorkach: Joies errantes i Intermèdes, znajdujemy rymy na końcu wersów. Kapryśność wierszy, nieustanna zmienność nastroju, płynne przechodzenie $z$ jednego rejestru do drugiego mają dużą wartość i zostały docenione przez wielu krytyków i czytelników. Zdaniem Ferdinanda Hausera, Krysinska jest artystką o tak szczególnej indywidualności, że nie mogłaby stworzyć szkoły, okazuje się jedyna w swoim rodzaju: „Od nikogo nie pochodzi i pozostawia za sobą świetlisty ślad jak kometa" 50 .

Konkludując, chciałabym przypomnieć, iż autorytety medyczne we Francji (i nie tylko) XIX wieku wątpiły w to, iż kobieta zdolna jest wznieść się do wyżyn intelektualnych mężczyzny ${ }^{51}$, i podkreślały, że jedynie on może być geniuszem. Jeśli pojawia się kobieta-geniusz, stanowi to aberrację natury. Krysinska podaje w wattpli-

Cyt. za: C. M en dè s, Le Mouvement poétique français de 1867 à 1900. Rapport à M. le Ministre de l'Instruction Publique et des Beaux-Arts [...]. Paris 1903, s. 149.

51 W Histoire morale des femmes z 1854 roku jej autor, E. Le g o u vé dowodzi, że największą zaletą kobiety jest brak zdolności rozumnego myślenia. Zastanawia się nawet, czy panna wykształcona (czytaj: znająca łacinę) zdolna jest do miłości. W roku 1895 w „Revue blanche” pojawia się tłumaczenie artykułu A. Strindberga o znamiennym tytule De l'infériorité de la femme et comme corollaire de la justification de sa situation subordonnée selon les données dernières de la science. W roku 1899 niemiecki lekarz, P.-J. M o e b i u s wydaje ksiażkę De la débilité mentale physiologique chez la femme, w której dowodzi, że kobieta jest tworem pośrednim między mężczyzną a dzieckiem, zarówno pod względem fizycznym, jak i psychicznym. 
wość kwestię relacji między płcią a geniuszem poetyckim, nie uznaje modyfikacji formuł poetyckich związanych z płcią i stanowczo zaprzecza, jakoby kreatywność, oryginalność nie mogły odnosić się do twórczości kobiet. Walka poetki o wiersz wolny to przede wszystkim walka o uznanie równości mężczyzn i kobiet w domenach nauki oraz sztuki.

O Krysinskiej należy pamiętać nie tylko w kontekście zjawiska wiersza wolnego (vers-librisme), ale także poezji scenicznej. Krysinska nie bała się kontaktu z publicznością, sama rozpoczęła $z$ nią dialog, najpierw w kabaretach „Les Hydropathes” i „Le Chat noir”, potem poprzez ogłaszanie drukiem wierszy na łamach czasopism i wydawanie tomików. Jej artykuły, przedmowy do kolejnych publikacji, spotkania $z$ czytelnikami i publicznością ${ }^{52}$ świadczą, że poetka wchodziła w rolę teoretyka i w sposób krytyczny uczestniczyła w recepcji własnych utworów ${ }^{53}$. Artystka eksperymentowała $z$ nowymi formami, nie tylko wiersza, ale także prezentacji scenicznej. Wraz z innymi poetami, m.in. Maurice'em Rollinatem, występującymi w klubach „Les Hydropathes” i „Le Chat noir”, ustanowiła strukturalny model dla przyszłych generacji poezji dźwięku. Słowo zapisane to tylko jeden $z$ aspektów twórczego działania, dla Krysinskiej liczyło się to, co André Breton nazwie później postawą (attitude) - wcielenie własnego tekstu, postawa egzystencjalna, uczynienie ze swojego życia dzieła sztuki i podważenie kanonów sztuki poetyckiej ${ }^{54}$.

Abstract

EWA MAŁGORZATA WIERZBOWSKA University of Gdańsk

\section{A SKETCH TO MARIE KRYSINSKA'S LITERARY PORTRAIT}

Marie Krysinska, a woman writer, composer and signer, made a substantial contribution to philosophy and aesthetics of her epoch. In her output she took up, inter alia, the issues of creativity, genius, and women's place in society. Her work is characterised by diversity of sources and influences as various arts, literature and science enter in it into a continuous discourse. Krysinska's connections with music constitute, e.g. her activity in two cabarets "Les Hydropathes" and "Le Chat noir". In 1880s she was engaged into a controversy over free verse (vers libre); she disallowed to diminish her role in introduction free verse into French poetry, for which her contemporaries and later critics punished her by exclusion. The fight she fought for the free verse is predominantly a fight for acknowledging equality of men and women in the domain of science and art.

Zob. D o n F a bric e: Propos de coulisses. „Gil Blas” 1902, nr 8119, z 6 II, s. 3: „W ostatnią środę, w teatrze des Capucines, wielki sukces pogadanki Pani Marii Krysinskiej na temat współczesnej Sztuki, Teatru i Poezji”; Propos de coulisses. Jw., nr 8142, z 4 III, s. 4: „W przyszłą środę, 5 marca, o 16.30, w teatrze des Capucines, będzie miała miejsce druga pogadanka Pani Krysinskiej o współczesnej sztuce, teatrze i poezji".

53 Zob. Marie Krysinska, s. 15.

54 Zob. Gade n, op. cit., s. 74. 